\title{
Counterfeit Norco Poisoning Outbreak - San Francisco Bay Area, California, March 25-April 5, 2016
}

\author{
Kathy T. Vo, MD ${ }^{1,2}$; Xander M.R. van Wijk, PhD ${ }^{3}$; Kara L. Lynch, PhD ${ }^{3}$; Alan H.B. Wu, PhD 3 ; Craig G. Smollin, MD 1,2
}

\author{
On April 26, 2016, this report was posted as an MMWR Early \\ Release on the MMWR website (http://www.cdc.gov/mmwr).
}

On March 28, 2016, two patients were evaluated at the Contra Costa Regional Medical Center emergency department (ED) in Contra Costa County, California, for nausea, vomiting, central nervous system depression, and respiratory depression, 30 minutes after ingesting what appeared to be Norco, a prescription opioid pain medication that contains acetaminophen and hydrocodone. The patients purchased the drug from a friend a few days earlier. The two cases of drug intoxication were reported to a Contra Costa County Health Department public health official who subsequently notified the California State Health Department.

Three days earlier, the Sacramento County Division of Public Health had released a Drug Overdose Health Alert regarding multiple poisoning overdoses related to ingestion of fentanyl-contaminated counterfeit Norco in Sacramento County (1). All staff members at the California Poison Control System (CPCS) were alerted to increase vigilance for potential cases. In the subsequent 2 weeks, the CPCS San Francisco Division identified an additional five cases in three Bay Area counties (Alameda, San Francisco, and Santa Clara), including one case in a patient (patient 1) that was reported retrospectively (Table). All patients reported to the CPCS San Francisco Division had various signs and symptoms of opioid intoxication after ingestion of the illicit product, and all recovered without clinical sequelae within 24 hours.

Although analyses of product and patient specimens from Sacramento County were reported to have contained fentanyl, all cases in the Bay Area also contained promethazine, which had not been reported as an additive in previous counterfeit or adulterated fentanyl-containing products. Fentanyl is a synthetic opioid analgesic that is a full $\mu$-opioid receptor agonist (one of the three opioid receptors through which opioids exert their pharmacologic actions) and has 100 times the potency of morphine (2). Fentanyl is available in many formulations, and its unique physicochemical properties, particularly its high lipophilicity, allow it to quickly enter the central nervous system and are responsible for its high potency (2) and high potential for abuse. Fentanyl is not currently formulated for oral administration in pill or tablet form, however, and its presence in pill form is a marker for an illicitly produced product. Promethazine, a phenothiazine derivative, is routinely prescribed for the treatment of nausea, vomiting, and motion sickness. Promethazine use has recently been reported to be common among chronic opioid users and is thought to potentiate the "high" from opioids (3).

\section{Initial Case Reports}

Patient 2 was a man aged 36 years who went to the ED with his girlfriend (patient 3), concerned that he was experiencing an adverse reaction to an illicitly purchased drug. He bought what he believed to be Norco tablets from a friend a few days earlier and described the tablets as having the inscription "M367," and looking exactly like Norco tablets that had been previously prescribed to him after a shoulder cartilage repair. He had ingested half of one street-purchased tablet approximately 12 hours earlier, and two additional tablets 30 minutes before arriving in the ED. In the ED, he was afebrile with stable vital signs and blood oxygen saturation $99 \%$ on room air. Electrolytes and blood chemistries were within normal ranges. Physical examination was notable for lethargy. He was administered a $0.4-\mathrm{mg}$ dose of intramuscular naloxone with transient improvement in his mental status; however, 1.5 hours later, he experienced respiratory depression with a decline in his oxygen saturation to $90 \%$, which improved with administration of supplemental oxygen. Acetaminophen level was $<10 \mu \mathrm{g} / \mathrm{mL}$. Urine drug screen was positive for opiates. He was observed for 6 hours and discharged home.

Patient 3, a woman aged 30 years, came to the ED with her boyfriend (patient 2), also having ingested two of the streetpurchased "Norco" tablets 30 minutes before arrival. After ingestion, she complained of dizziness and became unresponsive, and her boyfriend initiated cardiopulmonary resuscitation and contacted emergency responders, who noted that her blood oxygen saturation was $93 \%$ on room air. A $0.4-\mathrm{mg}$ dose of IV naloxone was administered, and on arrival at the ED, her physical exam was notable for lethargy and bradypnea (8 breaths/ minute), and blood oxygen saturation of $98 \%$ on $2 \mathrm{~L}$ of oxygen via nasal cannula. She received a second 0.4-mg dose of IV naloxone 6 hours after arrival. Laboratory results were normal except for a slightly elevated white blood cell count $(13,400 / \mu \mathrm{L}$ [normal $=4,000-10,000]$ ). Acetaminophen level was $<10 \mu \mathrm{g} / \mathrm{mL}$ and urine drug screen was positive for opiates. She had persistent nausea and vomiting, and was admitted to the hospital for 
TABLE. Laboratory findings from analyses of serum and urine specimens from seven patients reported to the California Poison Control System after exposure to counterfeit Norco - San Francisco Bay Area, California, March 25-April 5, 2016

\begin{tabular}{|c|c|c|c|c|c|c|c|c|}
\hline Patient no. & Date & Age (yrs) & Sex & $\begin{array}{l}\text { Serum fentanyl } \\
(\mathrm{ng} / \mathrm{mL})\end{array}$ & $\begin{array}{c}\text { Serum hydrocodone } \\
\text { (ng/mL) }\end{array}$ & $\begin{array}{c}\text { Serum acetaminophen } \\
(\mu \mathrm{g} / \mathrm{mL})\end{array}$ & $\begin{array}{l}\text { Additional drugs identified } \\
\text { in serum }\end{array}$ & $\begin{array}{l}\text { Drugs identified } \\
\text { in urine }\end{array}$ \\
\hline 1 & March 25 & 34 & Male & 8.4 & $<1.0$ (LLOQ) & 0.04 & $\begin{array}{c}\text { Alprazolam } \\
\text { Chlorpheniramine } \\
\text { Diazepam } \\
\text { Nordiazepam } \\
\text { Norfentanyl } \\
\text { Promethazine }\end{array}$ & $\begin{array}{l}\text { Specimen } \\
\text { not available }\end{array}$ \\
\hline 2 & March 28 & 36 & Male & 9.8 & 3.4 & 0.24 & $\begin{array}{c}\text { Benzoylecgonine } \\
\text { Diazepam } \\
\text { Dihydrocodeine } \\
\text { Diphenhydramine } \\
\text { Levamisole } \\
\text { Nordiazepam } \\
\text { Norfentanyl } \\
\text { Oxycodone } \\
\text { Promethazine }\end{array}$ & $\begin{array}{c}\text { Specimen } \\
\text { not available }\end{array}$ \\
\hline 3 & March 28 & 30 & Female & 3.8 & 3.1 & 1.19 & $\begin{array}{l}\text { Dihydrocodeine } \\
\text { Lamotrigine* } \\
\text { Lorazepam } \\
\text { Norfentanyl } \\
\text { Promethazine } \\
\text { Topimarate* } \\
\text { Trazodone* }\end{array}$ & $\begin{array}{c}\text { Specimen } \\
\text { not available }\end{array}$ \\
\hline 4 & April 2 & 18 & Female & 1.6 & Not detected & 0.20 & $\begin{array}{l}\text { Naloxone* } \\
\text { Norfentanyl } \\
\text { Promethazine } \\
\text { Theophylline }\end{array}$ & $\begin{array}{l}\text { Specimen } \\
\text { not available }\end{array}$ \\
\hline 5 & April 2 & 17 & Male & 10.1 & $<1.0$ (LLOQ) & 0.34 & $\begin{array}{c}\text { 11-nor-9-carboxy-THC } \\
\text { Alprazolam } \\
\text { Naloxone* } \\
\text { Norfentanyl } \\
\text { Promethazine }\end{array}$ & $\begin{array}{l}\text { Acetaminophen } \\
\text { Alprazolam } \\
\text { Fentanyl } \\
\text { Hydrocodone } \\
\text { Methamphetamine } \\
\text { Naloxone* } \\
\text { Norfentanyl } \\
\text { Promethazine }\end{array}$ \\
\hline 6 & April 5 & 54 & Male & 3.7 & 6.4 & 0.42 & $\begin{array}{c}\text { Benzoylecgonine } \\
\text { Gabapentin* } \\
\text { Levamisole } \\
\text { Naproxen* } \\
\text { Norfentanyl } \\
\text { Promethazine }\end{array}$ & $\begin{array}{l}\text { Benzoylecgonine } \\
\text { Cocaethylene } \\
\text { Cocaine } \\
\text { Codeine } \\
\text { Fentanyl } \\
\text { Gabapentin* } \\
\text { Hydrocodone } \\
\text { Hydromorphone } \\
\text { Naproxen* } \\
\text { Norfentanyl }\end{array}$ \\
\hline 7 & April 5 & 19 & Female & 4.9 & Not detected & 0.39 & $\begin{array}{c}\text { 11-nor-9-carboxy-THC } \\
\text { Lidocaine } \\
\text { Naloxone* } \\
\text { Norfentanyl } \\
\text { Promethazine }\end{array}$ & $\begin{array}{c}\text { Specimen } \\
\text { not available }\end{array}$ \\
\hline
\end{tabular}

Abbreviations: $\mathrm{LLOQ}=$ lower limit of quantification; $\mathrm{THC}=$ tetrahydrocannabinol.

* Confirmed as patient's prescribed medication or received before specimen collection.

overnight observation. Her symptoms improved, and she was discharged home 32 hours after her arrival.

\section{Laboratory Analyses}

Tablets purchased by another patient (patient 6) were provided to the hospital staff. The tablets and serum specimens from all seven patients were analyzed using liquid chromatography high-resolution mass spectrometry (4). Levels of fentanyl, acetaminophen, and hydrocodone were quantified. Additional drugs were also detected in the serum (Table).

Analysis of a tablet obtained from patient 6 indicated that it contained $3.5 \mathrm{mg}$ of fentanyl, $2.3 \mathrm{mg}$ of promethazine, $39.2 \mathrm{mg}$ of acetaminophen, and trace amounts of cocaine. All patients had serum fentanyl levels of 1.6-10.1 ng/mL (therapeutic range 


\section{Summary}

What is already known about this topic?

The United States is experiencing an opioid epidemic with synthetic opioids such as fentanyl responsible for the highest rise in death rates in recent years. Fentanyl, a potent opioid receptor agonist, can cause significant central nervous system and respiratory depression and has been implicated in multiple outbreaks in the past decade.

What is added by this report?

During March 25-April 5, 2016, seven cases of counterfeit Norco ingestion and intoxication were identified by the San Francisco Division of the California Poison Control System. Whereas Norco typically contains acetaminophen and hydrocodone, these counterfeit tablets predominantly contained fentanyl and promethazine. Prior to this outbreak in the Bay Area, counterfeit or adulterated fentanyl-containing products had not previously been reported to include promethazine as an additive. Promethazine likely potentiates the opioid effect.

What are the implications for public health practice?

The distribution of counterfeit tablets represents a major public health threat given the potentially lethal nature of the tablets. Health care providers should be aware of this and other concurrent outbreaks and notify local poison centers and health departments of suspected cases. Collaborative efforts among public health, medical, and law enforcement officials are essential for a rapid and effective response.

for analgesia $=0.6-3.0 \mathrm{ng} / \mathrm{mL}$ ), with all except one (patient 4 ) in excess of the therapeutic range (5). All patients had detectable acetaminophen levels, although well below therapeutic levels $(10-30 \mu \mathrm{g} / \mathrm{mL})$. Only three patients had hydrocodone levels above the lower level of quantification, and all were below the therapeutic level $(10-40 \mathrm{ng} / \mathrm{mL})$. Specimens from all patients contained promethazine.

\section{Discussion}

Response to this outbreak has included notification of the California Department of Public Health, local media outlets, and law enforcement officials. On April 4, 2016, the Drug Enforcement Administration (DEA) launched an anonymous tip line in San Francisco. No information has been released regarding the source of the counterfeit tablets, and an investigation is ongoing.

The distribution of counterfeit medications, especially those containing fentanyl, is an emerging and serious public health threat. Opioid abuse is the fastest-growing drug problem in the United States; despite prevention strategies at federal, state, and local levels, deaths caused by ingestion of opioid analgesics continue (๑). In addition to prescription drug abuse, nonpharmaceutical illicitly produced opioidcontaining products have received much attention in recent years. Fentanyl, in particular, was responsible for more than 1,000 deaths during 2005-2007 (7). In March 2015, DEA issued a nationwide alert about the dangers of illicitly produced fentanyl and fentanyl compounds, describing these products as a threat to health and public safety (8). In California, during October-December 2015, seven persons, including two who died, were found to have been exposed to fentanyl-adulterated counterfeit Xanax (9).

Efforts to identify the source of the current counterfeiting are ongoing. Patients with signs and symptoms of acute opioid overdose including central nervous system and respiratory depression, and in whom larger doses of naloxone are required to reverse symptoms, should raise suspicion for intoxication with a counterfeit product containing fentanyl. Physicians should inquire about the illegal purchase of prescription medications in these cases and notify their local poison control centers and health departments. Efforts should also be made to communicate to the general public the significant risks to life and health when purchasing what appears to be prescription medications from any source other than a reputable pharmacy or health care provider, because it might be difficult to distinguish a counterfeit pill from the legitimate pharmaceutical product (Figure).

FIGURE. Photo of four counterfeit Norco "M367" tablets obtained from patient 6 during the investigation of a counterfeit Norco poisoning outbreak — San Francisco Bay Area, California, 2016

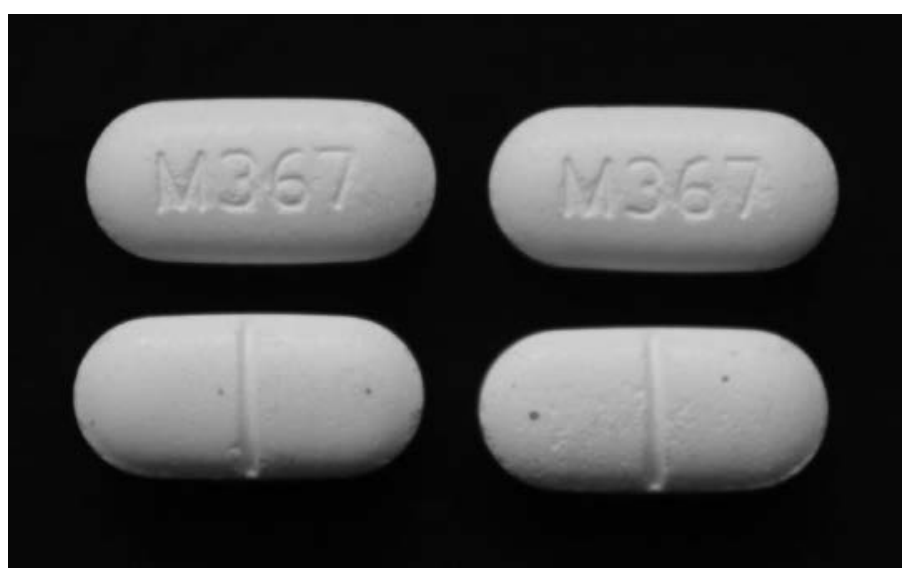

Photo/California Poison Control System, San Francisco Division

\footnotetext{
${ }^{1}$ Department of Emergency Medicine, University of California, San Francisco; ${ }^{2}$ California Poison Control System, San Francisco Division; ${ }^{3}$ Department of Laboratory Medicine, University of California, San Francisco.

Corresponding author: Kathy T. Vo, kathy.vo@ucsf.edu, 415-643-3243.
} 


\section{References}

1. County of Sacramento Health and Human Services Department. Drug overdose health alert: fentanyl-contaminated street Norco, March 25, 2016. http://www.dhhs.saccounty.net/PUB/Documents/AZ-Health-Info/ ME-20160325-Health+Alert+-+Contaminated+Norco.pdf

2. Lötsch J, Walter C, Parnham MJ, Oertel BG, Geisslinger G. Pharmacokinetics of non-intravenous formulations of fentanyl. Clin Pharmacokinet 2013;52:23-36. http://dx.doi.org/10.1007/ s40262-012-0016-7

3. Lynch KL, Shapiro BJ, Coffa D, Novak SP, Kral AH. Promethazine use among chronic pain patients. Drug Alcohol Depend 2015;150:92-7. http://dx.doi.org/10.1016/j.drugalcdep.2015.02.023

4. Thoren KL, Colby JM, Shugarts SB, Wu AH, Lynch KL. Comparison if information-dependent acquisition on a tandem quadrupole TOF vs a triple quadrupole linear ion trap mass spectrometer for broad-spectrum drug screening. Clin Chem 2016;62:170-8. http://dx.doi.org/10.1373/ clinchem.2015.241315
5. Peng PW, Sandler AN. A review of the use of fentanyl analgesia in the management of acute pain in adults. Anesthesiology 1999;90:576-99. http://dx.doi.org/10.1097/00000542-199902000-00034

6. CDC. CDC grand rounds: prescription drug overdoses - a U.S. epidemic. MMWR Morb Mortal Wkly Rep 2012;61:10-3.

7. CDC. Nonpharmaceutical fentanyl-related deaths — multiple states, April 2005-March 2007. MMWR Morb Mortal Wkly Rep 2008;57:793-6.

8. Drug Enforcement Administration. DEA issues nationwide alert on fentanyl as a threat to health and public safety, March 18, 2015. http:// www.dea.gov/divisions/hq/2015/hq031815.shtml

9. Arens AM, Vo KT, van Wijk X, Lemos N, Olson KR, Smollin C. Adulterated Xanax: a case series from San Francisco [Abstract]. From: abstracts from the 2016 American College of Medical Toxicology (ACMT) Annual Scientific Meeting, March 18-20, 2016, Huntington Beach, CA. 